\title{
Use of fibrinogen and thrombin sponge in pediatric split liver transplantation ${ }^{1}$
}

Fernando Pompeu Piza Vicentinel, Adriano Miziara Gonzalez", Barbara Burza Beninni"', Ramiro Anthero de Azevedo'v, Marcelo Moura Linhares", Alberto Goldenbergv, Gaspar de Jesus Lopes Filhov, Jose Luiz Martins ${ }^{\prime v}$, Alcides Augusto Salzedas Netto ${ }^{\prime V}$

'Fellow PhD degree, Postgraduate Program in Interdisciplinary Surgical Sciences, Universidade Federal de São Paulo (UNIFESP), Brazil. Conception and design of the study; acquisition, analysis and interpretation of data; statistics analysis; final approval of the version to be published.

"PhD, Associate Professor, Division of Surgical Gastroenterology, Department of Surgery, UNIFESP, Sao Paulo-SP, Brazil. Conception and design of the study; acquisition, analysis and interpretation of data; drafting the article; technical procedures, final approval of the version to be published.

I'IAssociate Professor, Division of Surgical Gastroenterology, Department of Surgery, UNIFESP, Sao Paulo-SP, Brazil. Intellectual content of the study; acquisition, analysis and interpretation of data.

IVPhD, Associate Professor, Division of Pediatric Surgery, Department of Surgery, UNIFESP, Sao Paulo-SP, Brazil. Conception and design of the study, analysis and interpretation of data, final approval of the version to be published.

${ }^{\vee}$ PhD, Chairman, Division of Surgical Gastroenterology, Department of Surgery, UNIFESP, Sao Paulo-SP, Brazil. Intellectual content of the study, final approval of the version to be published.

\section{Abstract}

Purpose: To analyze the use of this sponge in pediatric patients undergoing split-liver transplantation.

Methods: Retrospective study, including 35 pediatric patients undergoing split-liver transplantation, divided into two groups according to the use of the sponge: 18 patients in Group A (no sponge) and 17 in Group B (with sponge).

Results: The characteristics of recipients and donors were similar. We observed greater number of reoperation due to bleeding in the wound area in Group A (10 patients- $55.5 \%$ ) than in Group B (3 patients-17.6\%); $p=0.035$. The median volume of red blood cells transfused in Group A was significantly higher $(73.4 \pm 102.38 \mathrm{~mL} / \mathrm{kg})$ than that in Group B $(35.1 \pm 41.67$ $\mathrm{mL} / \mathrm{kg}) ; \mathrm{p}=0.048$. Regarding bile leak there was no statistical difference.

Conclusion: The use of the human fibrinogen and thrombin sponge, required lower volume of red blood cell transfusion and presented lower reoperation rates due to bleeding in the wound area.

Key words: Liver Transplantation. Homeostasis. Fibrinogen. Thrombin. 


\section{- Introduction}

Pediatric liver transplantation is associated with good results in the literature, achieving survival rates at 1 year of more than $90 \%{ }^{1-5}$. However, it is difficult to find deceased liver donors with suitable grafts for small recipients ${ }^{6-8}$. In addition to the shortage of organs for transplantation from deceased donors, the mortality of the patients in waiting lists is a concerning reality $y^{3,9-11}$.

Some techniques have been developed as surgical alternatives to increase the number of viable liver grafts available for liver transplantation and reduce the mortality rates in liver transplant waiting lists. One such technique is split-liver transplantation ${ }^{12-14}$, described by Pichlmayr et al. ${ }^{15}$. In this technique, a liver graft from a cadaver donor is divided on an auxiliary table respecting the anatomical liver segments while preserving their vascular structures, yielding two partial grafts suitable for transplantation into two distinct recipients. Grafts with liver segments II and III are transplanted into pediatric recipients, while those with segments I and IVVIII are transplanted into adult ones (Figure 1).

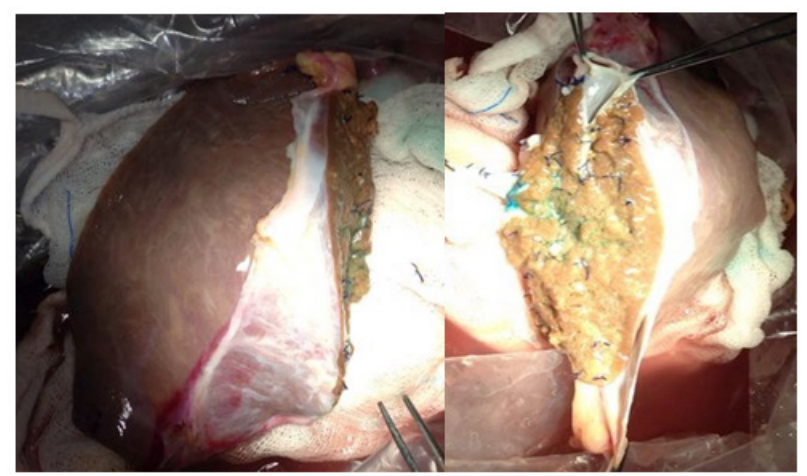

Figure 1 - Hepatic graft with split technique, with the formation of two liver grafts suitable for transplantation.

According to the current literature, the split technique has good results, with survival rates similar to those obtained with whole graft transplants $s^{6,7,12,16,17}$. However, the split technique may be associated with complications such as increased bleeding in the wound area, greater requirement of red blood cell transfusion, and occurrence of biliary leak ${ }^{12,16-18}$.

The human fibrinogen and thrombin sponge (TachoSil ${ }^{\circ}$, Takeda, Linz, Austria) ${ }^{19}$ is a useful tool in surgical hemostasis that consists of a collagen matrix with a layer of plasma components such as clotting factors, fibrinogen, and fibrin. The use of the sponge in liver surgery has been described in large studies demonstrating that after hepatectomy (surgery in which an open wound is created in the liver), the use of the sponge obtained rapid and effective hemostasis at the bleeding area when compared with other methods $\mathrm{s}^{20-23}$.

The sponge has been used in pediatric patients undergoing liver transplantation, in a case series in which two children received the left segment of the liver from a living donor, while two others received a reduced graft. In all four cases, the sponge was used in the open area of the graft with optimal and effective hemostasis ${ }^{24}$.

Regarding biliary leak (another possible complication in the wound area created during the split), the sponge has been studied in adults undergoing liver transplantation with the split technique, showing that the use of the sponge was associated with a lower incidence of biliary fistula in the open area of the liver graft ${ }^{18}$.

Based on these considerations, the objective of this study was to analyze the use of the human fibrinogen and thrombin sponge in pediatric patients undergoing split-liver transplantation.

\section{Methods}

The project of this study was approved by the Ethics Committee at Universidade Federal de São Paulo (UNIFESP), number 38311,18 June 2012.

This was a retrospective study 
conducted from September 2009 to April 2016 including pediatric patients undergoing splitliver transplantation at Hospital São Paulo, UNIFESP.

The study included 35 patients divided into two groups according to the use of the sponge during transplantation: 18 patients allocated to Group A (without the sponge) and 17 to Group B (with the sponge).

Potential donors for the split-liver transplantation were selected when matching most of the criteria established by our institution, as previously established in the literature: age below 50 years, hemodynamic stability, fewer than 4 days in the intensive care unit, levels of alanine aminotransferase (ALAT, $\mathrm{U} / \mathrm{L}$ ) and aspartate aminotransferase (ASAT, $\mathrm{U} / \mathrm{L}$ ) below twice the normal levels, gammaglutamyltransferase (GGT) lower than $50 \mathrm{IU} / \mathrm{L}$, serum sodium level below $160 \mathrm{mmol} / \mathrm{L}$, and less than $20 \%$ of fatty infiltration of the liver on macroscopic analysis.

The split technique was performed in a standard way, and the arterial trunk and left portal branch were dissected in order to remain within the graft comprising segments II and III. When visible, vascular and biliary structures within the liver parenchyma were ligated with cotton thread and thick gauges vessels were reinforced with 4-0 polypropylene sutures (Figure 2).

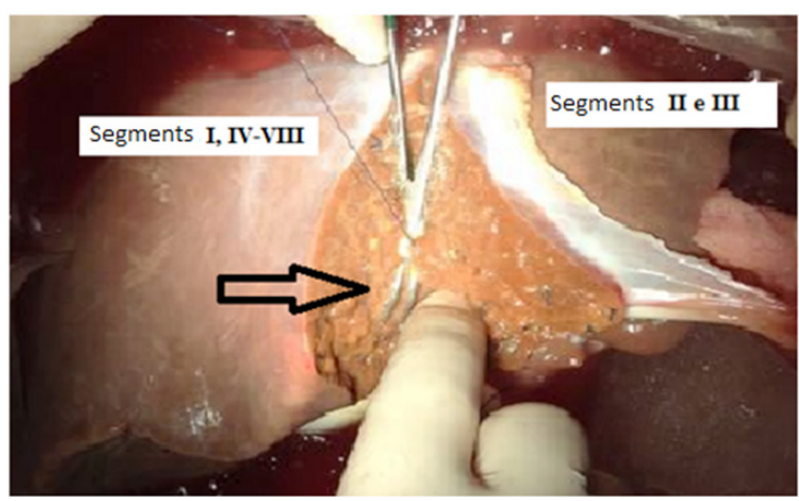

Figure $\mathbf{2}$ - Transection of the hepatic graft with the split technique.
To observe correctly the hilar plate and perform a bile duct section, we injected methylene blue solution into the bile duct to achieve an adequate and correct visibility of the structure. We then dissected and sectioned the hilar plate in order to obtain a single bile duct hole in the graft with segments II and III, as the location for future reconstruction during liver transplantation.

After reperfusion of the liver graft, primary hemostasis was performed in the open area with sutures, bandages, and mono- and bipolar electrocautery. Similarly, we performed suture and ligature of possible biliary leak points that could potentially lead to postoperative leakage. Following instructions from the manufacturer, we used pre-moistened sponges and applied their yellow side (the side which has the active ingredients) on the wound surface of the liver graft.

We performed sponge compression for about 2 minutes with the help of a wet compress, in order to obtain a correct fixation of the sponge and local hemostasis. Since the extension of the open area is greater than the surface of the sponge, we used, when necessary, more than one sponge and repeated the same process (Figure 3).

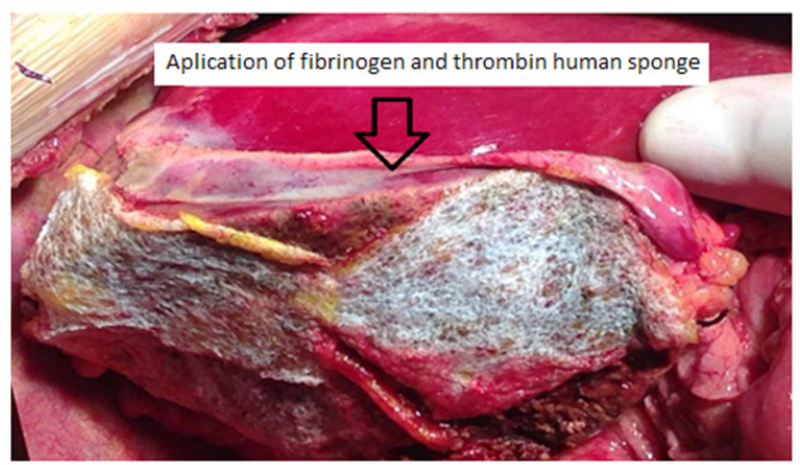

Figure 3 - Fibrinogen sponge application and human thrombin in the open area of pediatric liver graft with the split technique.

This study evaluated the demographic characteristics of the recipients, use of 
red blood cell transfusion during split-liver transplantation (in $\mathrm{mL} / \mathrm{kg}$ ), reoperation due to wound bleeding, occurrence of biliary leak in the open area and graft, and patient survival at 30 days.

The analyzed data are expressed as mean, median, standard deviation, and percentage. The statistical analysis was performed with the help of a professional statistician. We used the tests Student's t, chi-square, Fisher's exact and Mann-Whitney, as well as Kaplan-Meier survival curves as indicated.

We performed the statistical analysis using the software SPSS, version 2.0, and considered $p$ values $<0.05$ as significant.

\section{Results}

As shown in Table 1, both groups were comparable and had no significant differences in the evaluated parameters.

Table 1 - Demographic characteristics of the study population.

\begin{tabular}{llll}
\hline & $\begin{array}{l}\text { Group A } \\
\text { (n=18) } \\
\text { Without the } \\
\text { Sponge }\end{array}$ & $\begin{array}{l}\text { Group B } \\
\text { (n=17) } \\
\text { With the } \\
\text { Sponge }\end{array}$ & p \\
\hline $\begin{array}{l}\text { Age } \\
\text { (years) }\end{array}$ & $1.5 \pm 1,2$ & $1,4 \pm 1,8$ & 0.85 \\
Sex & M: 7 & M: 9 & 0.5 \\
$\begin{array}{l}\text { Weight } \\
\text { (kg) }\end{array}$ & $11.13 \pm 14.30$ & $10.42 \pm 9.7$ & 0.86 \\
$\begin{array}{l}\text { Height } \\
\text { (cm) }\end{array}$ & $68.26 \pm 11.06$ & $68.5 \pm 13.32$ & 0.95 \\
PELD & $19.95 \pm 8.91$ & $25.58 \pm 13.32$ & 0.08 \\
score & & &
\end{tabular}

M. males; F. females; PELD score. Pediatric End-Stage Liver Disease score

Regarding the analyzed parameters (Table 2), the median volume of red blood cells transfused in Group A was significantly higher
$(73.4 \pm 102.38 \mathrm{~mL} / \mathrm{kg})$ than that in Group $B$ (35.1 $\pm 41.67 \mathrm{~mL} / \mathrm{kg} ; \mathrm{p}=0.048)$.

When we analyzed those cases that required reoperation due to bleeding in the wound area of the liver graft, we observed a significantly greater number of these patients in Group A (10 patients - 55.5\%) than in Group $B$ (3 patients $-17.6 \% ; p=0.035)$.

Regarding biliary leak in the wound area, there was no statistical difference comparing both groups, with Group A rate showing a rate of $11.1 \%$ and Group $B$ a rate of $17.6 \%(p=0.65)$.

At 30 days, patient survival rates were $75 \%$ in Group A and $87.5 \%$ in Group B ( $p=$ $0.36)$, while graft survival rates were $75 \%$ and $81.25 \%$, respectively $(p=0.11)$.

Table 2 - Results of analyzed parameters.

\begin{tabular}{llll}
\hline & $\begin{array}{l}\text { Group A } \\
\text { (n=18) } \\
\text { Without } \\
\text { Sponge }\end{array}$ & $\begin{array}{l}\text { Group B } \\
\text { (n=17) } \\
\text { With } \\
\text { Sponge }\end{array}$ & p \\
\hline $\begin{array}{l}\text { Red blood } \\
\text { cells } \\
\text { transfused } \\
\text { (ml/Kg) }\end{array}$ & $73.4 \pm 102.38$ & $35.1 \pm 41.67$ & 0.040 \\
$\begin{array}{l}\text { Reoperation } \\
\text { due to } \\
\text { bleeding in } \\
\text { the wound } \\
\text { area }\end{array}$ & $10(55 \%)$ & $3(17.6 \%)$ & 0.035 \\
$\begin{array}{l}\text { Biliary leak } \\
\text { in the wound } \\
\text { area }\end{array}$ & $2(11.1 \%)$ & $3(17.6 \%)$ & 0.65 \\
\hline
\end{tabular}

\section{Discussion}

The demographic characteristics of the patients in whom the human fibrinogen and thrombin sponge was used during split-liver transplantation were statistically comparable to those in whom the sponge was not used, thus comprising two similar and comparable groups for the analysis of possible outcomes. 
Regarding the median volume of red blood cells transfused during liver transplantation, a greater volume was used in Group A (without the sponge) when compared with Group B (with the sponge). A similar observation has been described in a study comparing the use of the human fibrinogen and thrombin sponge in adult patients undergoing split-liver transplantation, which found a lower requirement of blood transfusion in patients with the use of the sponge ${ }^{25}$.

We observed a significantly higher rate of reoperation due to bleeding in the wound area in Group A when compared with Group $B$, showing that the sponge can improve hemostasis in the open area in pediatric patients undergoing split-liver transplantation. This finding is corroborated in the literature assessing the use of the sponge for hemostasis of the bleeding liver area after hepatectomy and liver transplantation with the split technique and / or living donor ${ }^{1,18,20-24}$.

In 2008, a traditional group of pediatric transplantation in Belgium published their experience with the use of the sponge in four children undergoing liver transplantation with the liver transection technique (two children received the left segment of the liver from a living donor and two received a reduced liver graft). Although this case series lacked a control group, the opinion of the authors was that the human fibrinogen and thrombin sponge performs optimal and effective hemostasis in the open area of the graft. They based their conclusion on their observation that only one concentrate of red blood cells was used per patient during transplantation and that none of the patients presented post-surgical bleeding ${ }^{24}$.

Mirza et al. ${ }^{1}$ published a prospective, multicenter study analyzing the use of the sponge in patients undergoing liver transplantation with an ex-situ liver transection technique and others undergoing hepatectomy. They included 16 patients in the study, of whom 13 underwent liver transplantation. The authors demonstrated an optimal hemostasis of the bleeding area with the use of the sponge for up to 3 minutes in $81 \%$ of the patients studied.

In the present study, there was no significant difference in biliary leak rates in the wound area when we compared Groups $A$ and B. Biliary leak in liver transplantation is directly related to complications in the hepatic artery and an important cause of morbidity, with rates in the literature ranging from 5 to $10 \%$ in whole-liver transplantation ${ }^{26-28}$. In cases of liver transplantation with the split technique, these rates may increase ${ }^{28,29}$, reaching about $18.8 \%$, as described by Diamond et al..$^{30}$.

The use of the human fibrinogen and thrombin sponge and its association with biliary leak and collection of the wound area is still controversial in the literature. Toti et al. ${ }^{18}$ published a retrospective study showing a reduction in biliary leak rates in adult patients undergoing liver transplantation with the split technique and the use in the wound area of the human fibrinogen and thrombin sponge compared with fibrin glue. The authors found a reduction in biliary leak rate from $43.75 \%$ without the sponge to $6.25 \%$ with the sponge. In contrast, Mirza et al. ${ }^{1}$ have shown a $12.5 \%$ reoperation rate due to biliary leak in the open area in pediatric patients undergoing liver transplantation, regardless of the use or nonuse of the human fibrinogen and thrombin sponge.

Both groups showed comparable 30day rates in terms of mortality and graft loss. The early survival (at 30 days) was based on the sponge absorption, that occurs in this period.

The present study is limited by its retrospective design, although the data were prospectively collected in a spreadsheet. An important strength of the study was the fact that all the transplantations were performed by the same team in which all members had already completed their learning curves at the beginning of the study. 


\section{Conclusion}

The use of the human fibrinogen and thrombin sponge, when compared with no use of the sponge, required a lower volume of red blood cell transfusion during the procedure and presented lower reoperation rates due to bleeding in the wound area.

\section{References}

1. Mirza D, Millar AJ, Sharif K, Vilca-Melendez $H$, Rela M, Heaton N. The use of TachoSil in children undergoing liver resection with or without segmental liver transplantation. Eur J Pediatr Surg. 2011 Mar;21(2):111-5. doi: 10.1055/s-0030-1267221.

2. Hackl C, Schlitt HJ, Melter M, Knoppke B, Loss M. Current developments in pediatric liver transplantation. World J Hepatol. 2015 Jun 18;7(11):1509-20. doi: 10.4254/wjh. v7.i11.1509.

3. Rana A, Pallister Z, Halazun K, Cotton R, Guiteau J, Nalty CC, O'Mahony CA, Goss JA. Pediatric liver transplant center volume and the likelihood of transplantation. Pediatrics. 2015 Jul;136(1):e99-e107. doi: 10.1542/ peds.2014-3016.

4. Feier $F$, Antunes E, D'Agostino D, VarelaFascinetto $G$, Jarufe $N$, Patillo JC, Vera A, Carrasco F, Kondo M, Porta G, Chapchap P, Seda-Neto J. Pediatric liver transplantation in Latin America: where do we stand? Pediatr Transplant. 2016 May;20(3):408-16. doi: 10.1111 petr.12679.

5. Emre S, Umman V. Split liver transplantation: an overview. Transplant Proc. 2011 Apr;43(3):884-7. doi: 10.1016/j. transproceed.2011.02.036.

6. Doyle MB, Maynard E, Lin Y, Vachharajani N, Shenoy S, Anderson C, Earl M, Lowell $J A$, Chapman WC. Outcomes with split liver transplantation are equivalent to those with whole organ transplantation. J Am Coll Surg. 2013 Jul;217(1):102-12; discussion 13-4. doi: 10.1016/j.jamcollsurg.2013.03.003.

7. Renz JF, Yersiz H, Reichert PR, Hisatake GM, Farmer DG, Emond JC, Busuttil RW. Split-liver transplantation: a review. Am J Transplant. 2003 Nov;3(11):1323-35.

8. Dalal AR. Split liver transplantation: what's unique? World J Transplant. 2015 Sep
24;5(3):89-94. doi: 10.5500/wjt.v5.i3.89.

9. García-Valdecasas JC. Split and living donor liver transplantation. Dig Liver Dis Suppl. 2009 Dec;3(4):93-5. doi: 10.1016/S15945804(09)60033-4.

10.Semer NB. Awaiting liver transplantation. Transplantation. 2015 Jul;99(7):e48. doi: 10.1097/TP.0000000000000755.

11.Associação Brasileira de Transplante de Órgãos. Dimensionamento dos transplantes no Brasil e em cada estado (2008-2015) [Internet]. São Paulo: ABTO; 2015 [cited 2017 Jul 6]. 88 p. (Registro Brasileiro de Transplantes; vol. 21, no. 4). Available from: http://www.abto.org.br/abtov03/Upload/ file/RBT/2015/anual-n-associado.pdf

12.Salzedas-Netto AA, Amadei HL, Castro CC, Mattar RH, Medeiros KL, Linhares MM, Duarte AA, Chinen ES, Marino GC, Matos CA, Lopes-Filho G, Martins JL, Gonzalez AM. Impact of liver ex situ transection on pediatric liver transplantation. Transplant Proc. 2010 Mar;42(2):507-10. doi: 10.1016/j. transproceed.2010.01.040.

13.Gong N, Chen X. Partial liver transplantation. Front Med. 2011 Mar;5(1):1-7. doi: 10.1007/ s11684-010-0105-7.

14.Oswari H, Lynch SV, Fawcett J, Strong RW, Ee LC. Outcomes of split versus reducedsize grafts in pediatric liver transplantation. J Gastroenterol Hepatol. 2005 Dec;20(12):1850-4. doi: 10.1111/j.14401746.2005.03926.x.

15.Pichlmayr R, Ringe B, Gubernatis G, Hauss J, Bunzendahl H. Transplantation of a donor liver to 2 recipients (splitting transplantation): a new method in the further development of segmental liver transplantation. Langenbecks Arch Chir. 1988;373(2):127-30. PMID: 3287073.

16. Lauterio A, Di Sandro S, Concone G, De Carlis R, Giacomoni A, De Carlis L. Current status and perspectives in split liver transplantation. World J Gastroenterol. 2015 Oct 21;21(39):11003-15. doi: 10.3748/ wjg.v21.i39.11003.

17.Foster R, Zimmerman M, Trotter JF. Expanding donor options: marginal, living, and split donors. Clin Liver Dis. 2007 May;11(2):417-29. doi: 10.1016/j. cld.2007.04.004.

18.Toti L, Attia M, Manzia TM, Lenci I, Gunson B, Buckels JA, Mirza DF, Mayer AD, Bramhall SR, Wigmore SJ. Reduction in bile leaks following adult split liver transplant using 
a fibrin-collagen sponge: a pilot study. Dig Liver Dis. 2010 Mar;42(3):205-9. doi: 10.1016/j.dld.2009.06.010.

19. TachoSil ${ }^{\circledR}$ : fibrinogênio + trombina. São Paulo: Takeda Pharma Ltda; 2015 Dec. Package insert.

20.Frilling A, Stavrou GA, Mischinger HJ, de Hemptinne B, Rokkjaer M, Klempnauer J, Thorne A, Gloor B, Beckebaum S, Ghaffar MF, Broelsch CE. Effectiveness of a new carrierbound fibrin sealant versus argon beamer as haemostatic agent during liver resection: a randomised prospective trial. Langenbecks Arch Surg. 2005 Apr;390(2):114-20. doi: 10.1007/s00423-005-0543-x.

21.Briceno J, Naranjo A, Ciria R, Diaz-Nieto $R$, Sanchez-Hidalgo JM, Luque A, Rufian $S$, Lopez-Cillero P. A prospective study of the efficacy of clinical application of a new carrier-bound fibrin sealant after liver resection. Arch Surg. 2010 May;145(5):4828. doi: 10.1001/archsurg.2010.62.

22.Fischer L, Seiler CM, Broelsch CE, de Hemptinne B, Klempnauer J, Mischinger HJ, Gassel HJ, Rokkjaer M, Schauer R, Larsen PN, Tetens V, Buchler MW. Hemostatic efficacy of TachoSil in liver resection compared with argon beam coagulator treatment: an open, randomized, prospective, multicenter, parallel-group trial. Surgery. 2011 Jan;149(1):48-55. doi: 10.1016/j. surg.2010.02.008.

23. Rickenbacher A, Breitenstein S, Lesurtel $M$, Frilling A. Efficacy of TachoSil a fibrinbased haemostat in different fields of surgery: a systematic review. Expert Opin Biol Ther. 2009 Jul;9(7):897-907. doi: 10.1517/14712590903029172.

24.Lacanna F, Brunati A, Reding R. A new biological mesh for cut surface hemostasis in liver transplantation using technical variants. Pediatr Transplant. 2008 Aug;12(5):520-1. PMID: 18672482.

25.Vicentine F, Perdigao F, Goumard G, Brustia $R$, Sepulveda A, Soubrane O, Scatton O. Use of absorbable fibrin sealant patch (Tachosil) for hemostasis in split liver transplantation. HPB (Oxford). 2016 Apr;18 Suppl 1:e272-3. doi: 10.1016/j.hpb.2016.02.691.

26.Seehofer D, Eurich D, Veltzke-Schlieker W, Neuhaus P. Biliary complications after liver transplantation: old problems and new challenges. Am J Transplant. 2013 Feb;13(2):253-65. doi: 10.1111/ajt.12034.

27.Lastovickova J, Peregrin J. Biliary strictures after orthotopic liver transplantation: long-term results of percutaneous treatment in patients with nonfeasible endoscopic therapy. Transplant Proc. 2012 Jun;44(5):1379-84. doi: 10.1016/j. transproceed.2012.02.026.

28.Duailibi DF, Ribeiro MA Jr. Biliary complications following deceased and living donor liver transplantation: a review. Transplant Proc. 2010 Mar;42(2):517-20. doi: 10.1016/j.transproceed.2010.01.017.

29. Feier FH, da Fonseca EA, Seda-Neto J, Chapchap P. Biliary complications after pediatric liver transplantation: risk factors, diagnosis and management. World J Hepatol. 2015 Aug 28;7(18):2162-70. doi: 10.4254/wjh.v7.i18.2162.

30.Diamond IR, Fecteau A, Millis JM, Losanoff $\mathrm{JE}$, Ng V, Anand R, Song C. Impact of graft type on outcome in pediatric liver transplantation: a report from Studies of Pediatric Liver Transplantation (SPLIT). Ann Surg. 2007 Aug;246(2):301-10. doi: 10.1097/ SLA.0b013e3180caa415.

\section{Correspondence:}

Fernando Pompeu Piza Vicentine

Rua Napoleao de Barros, 715/2ㅇ andar

04024-022 São Paulo - SP Brasil

Tels.: (55 11)5576-4522 / 5576-4053

fernandoppv@yahoo.com.br

Received: Apr 12, 2017

Review: June 14, 2017

Accepted: July 18, 2017
Conflict of interest: none

Financial source: none

'Research performed at Division of Surgical Gastroenterology, Department of Surgery, Universidade Federal de São Paulo (UNIFESP), Brazil. Part of PhD degree thesis, Postgraduate Program in Interdisciplinary Surgical Sciences. Tutor: Prof. Dr. Alcides Augusto Salzedas Netto. 